\title{
Confirmation of an association between RFLPs at the transforming growth factor-alpha locus and non-syndromic cleft lip and palate
}

\author{
S E Holder, G M Vintiner, B Farren, S Malcolm, R M Winter
}

\begin{abstract}
Three RFLPs at the TGFA locus were studied in 60 unrelated British Caucasian subjects with non-syndromic cleft lip/ palate and 60 controls. A highly significant association between the TaqI RFLP and the occurrence of clefting was found $\left(x^{2}=15.04, p=<0.001\right)$. No significant association was found with the two other RFLPs studied (BamHI and RsaI). Haplotypes derived from the three RFLPs at the TGFA locus also showed an overrepresentation of the $\mathrm{C} 2 \mathrm{~A} 2 \mathrm{~B} 2$ haplotype in cases compared to controls. Analyses of genotypes according to type of cleft and the presence or absence of a family history of clefting were also carried out. These results provide further support for the role of TGFA as a gene of major effect in the development of orofacial clefts in humans.
\end{abstract}

In 1989 Ardinger $e$ e $a l^{1}$ reported an association between two out of three restriction fragment length polymorphisms (RFLPs) around the transforming growth factor-alpha (TGFA) gene and non-syndromic cleft lip with or without cleft palate $(\mathrm{CL} / \mathrm{P})$ in white Americans. A similar study in an Australian population of Anglo-Celtic descent showed a significant association with one of the RFLPs at the TGFA locus. $^{2}$

Cleft lip, with or without cleft palate, is one of the commonest serious craniofacial malformations, with an incidence of between 1 in 700 and 1 in 1000 live births. In the past, almost every possible mode of inheritance has been postulated to attempt to explain the observed increased risk of recurrence of $\mathrm{CL} / \mathrm{P}$ within families. ${ }^{3}$ The most widely accepted model is that of multifactorial inheritance, whereby the trait is determined by the interaction of genetic and environmental factors. ${ }^{4}$ However, recent studies using complex segregation analysis have suggested that the observed pedigree data can best be explained by the effect of a major gene, modified by various genetic or environmental factors or

Table 1 TGFA RFLPs.

\begin{tabular}{|c|c|c|c|c|c|}
\hline & & & Polymorphism & Frequency & \\
\hline Probe & Location & Enzyme & Allele $1 /$ allele 2 & Allele 1 /allele 2 & Ref \\
\hline $\begin{array}{l}\text { phTGF1-10-3350 } \\
\text { phTGF1-10-925 }\end{array}$ & $2 \mathrm{p} 13$ & $\underset{\substack{\text { TamH I I } \\
\text { RsaI }}}{T a q}$ & $\begin{array}{l}3.0 \mathrm{~kb} / 2.7 \mathrm{~kb} \\
9.0 \mathrm{~kb} / 3.7 \mathrm{~kb} \\
1.5 \mathrm{~kb} / 1.2 \mathrm{~kb}\end{array}$ & $\begin{array}{l}0.94 / 0 \cdot 06 \\
0 \cdot 19 / 0.81 \\
0 \cdot 29 / 0.71\end{array}$ & $\begin{array}{r}9 \\
10 \\
10\end{array}$ \\
\hline
\end{tabular}

both. ${ }^{5}$ This observation has led to a number of groups attempting to identify the major gene(s) involved in facial clefting, using a variety of genetic techniques, such as association and linkage studies. The report, in 1989, of an association between CL/P and RFLPs at the TGFA locus in a white American population led us to investigate a group of white British cleft subjects for the same association. A separate linkage study on families with $\mathrm{CL} /$ $P$ was also carried out using TGFA. ${ }^{6}$

\section{Materials and methods}

Blood samples were collected from 60 unrelated white British people with non-syndromic $\mathrm{CL} / \mathrm{P}$. The subjects were ascertained through various sources, including CLAPA (the support organisation), the North West Thames Regional Genetic Service, based at Northwick Park Hospital, and the CLAPA clinic at The Hospital for Sick Children, Great Ormond Street, London. Most subjects were visited at home and a detailed family history and pregnancy history (when available) was obtained. A clinical examination to look for dysmorphic features (such as lip pits) was undertaken. Cases were excluded from the study if there was evidence of prenatal exposure to any prescribed medication (such as phenytoin), if other dysmorphic features were present (such as lip pits, congenital heart lesion, etc), or if the subject was one of twins. This left 57 cases available for study. A control group consisted of 37 DNA samples from unrelated parents of children with cystic fibrosis (with no information available with regard to the presence of clefting but assumed to be normal) and 23 DNA samples from colleagues in the two centres involved in the study.

\section{DNA ANALYSIS}

DNA was extracted from whole blood using a modification of the technique described by Jeanpierre $^{7} ; 5 \mu \mathrm{g}$ of DNA were digested with each of the three restriction enzymes under study (table 1), using appropriate conditions. DNA fragments were separated on $0.8 \%$ agarose gels, denatured in $1.5 \mathrm{~mol} / 1 \mathrm{NaCl} / 0.5 \mathrm{~mol} / 1$ $\mathrm{NaOH}$ solution and transferred onto Hybond $\mathrm{N}+$ membrane using the Southern blotting technique. $^{8}$ The TGFA probe insert was labelled with ${ }^{32} \mathrm{P}$ CTP and then preannealed with boiled sonicated human DNA at a concentration of $10 \mathrm{mg} / \mathrm{ml}$ for 30 minutes at $65^{\circ} \mathrm{C}$, in order to remove repetitive sequences. 
Table 2 Distribution of types of cleft.

\begin{tabular}{lrr}
\hline & No & $\%$ \\
\hline Bilateral cleft lip and palate & 15 & 27 \\
Bilateral cleft lip & 1 & 2 \\
Right sided cleft lip and palate & 9 & 16 \\
Right sided cleft lip & 7 & 12 \\
Left sided cleft lip and palate & 13 & 23 \\
Left sided cleft lip & 11 & 20 \\
\hline
\end{tabular}

Table 3 Genotype data by cleft type.

\begin{tabular}{lccc}
\hline Genotype & Bilateral CL/P & Unilateral CL/P & Total \\
\hline C2C2 & 3 & 1 & 4 \\
C1C2 & 3 & 11 & 14 \\
C1C1 & 10 & 26 & 36 \\
Total & 16 & 38 & 54 \\
\hline
\end{tabular}

Hybridisation at $65^{\circ} \mathrm{C}$ was followed by washing filters in $0.1 \times \mathrm{SSC} / 0.1 \% \mathrm{SDS}$ at $65^{\circ} \mathrm{C}$. Subsequent autoradiography was carried out using Kodak Diagnostic X-ray film exposed for seven days at $-70^{\circ} \mathrm{C}$. The resulting autoradiographs were scored for the presence of the various polymorphic alleles (table 1 ).

\section{STATISTICAL ANALYSIS}

$\chi^{2}$ analysis was used to assess allele and haplotype frequency differences between cases and controls. Haplotypes and genotypes were derived from the RFLP data where possible. It was not possible to construct haplotypes for those subjects who were doubly (or trebly) heterozygous for the various RFLPs, and this potentially could have introduced a disproportionate bias when comparing the frequency of the various haplotypes in the two different populations.

\section{Results}

Table 2 shows the distribution of cleft types for the 56 subjects for whom information on cleft type was known, and shows the excess of left sided cleft lip, as has been observed in previous surveys. ${ }^{11}$ These data were subsequently analysed according to genotype (table 3).

Table 4 shows the allele and genotype frequencies for TGFA and the three enzymes under study. The increased occurrence of the TGFA/TaqI $1.7 \mathrm{~kb}$ allele (C2) in the presence of clefting can be seen. Table 5 gives the RFLP distribution in cases and controls. In a

Table 4 TGFA allele and genotype frequencies.

\begin{tabular}{lccccc}
\hline Subject type (No) & \multicolumn{2}{c}{ Allele* frequency } & \multicolumn{3}{c}{ Genotype No (\%) } \\
\hline CL/P (55) & C1 & C2 & C1C1 & C1C2 & C2C2 \\
Control (60) & 0.79 & 0.21 & $36(66)$ & $14(26)$ & $5(9)$ \\
& 0.96 & 0.04 & $55(92)$ & $5(8)$ & 0 \\
CL/P (57) & $\mathrm{A} 1$ & $\mathrm{~A} 2$ & $\mathrm{~A} 1 \mathrm{A1}$ & $\mathrm{A} 1 \mathrm{A2}$ & $\mathrm{A} 2 \mathrm{A2}$ \\
Control (60) & 0.12 & 0.88 & $2(3)$ & $10(18)$ & $45(79)$ \\
& 0.13 & 0.87 & 0 & $16(27)$ & $44(73)$ \\
CL/P (57) & $\mathrm{B} 1$ & $\mathrm{~B} 2$ & $\mathrm{~B} 1 \mathrm{~B} 1$ & $\mathrm{~B} 1 \mathrm{~B} 2$ & $\mathrm{~B} 2 \mathrm{~B} 2$ \\
Control (59) & 0.39 & 0.61 & $9(16)$ & $27(47)$ & $21(37)$ \\
& 0.36 & 0.64 & $10(17)$ & $22(37)$ & $27(46)$ \\
\hline
\end{tabular}

* TGFA/TaqI: Cl $=3.0 \mathrm{~kb}, \mathrm{C} 2=2.7 \mathrm{~kb}$; TGFA $/$ BamHI: $\mathrm{Al}=9.0 \mathrm{~kb}, \mathrm{~A} 2=3.7 \mathrm{~kb}$; TGFA $/ R s \mathrm{I}$ : $\mathrm{Bl}=1.5 \mathrm{~kb}, \mathrm{B2}=1.2 \mathrm{~kb}$. few cases, no results were obtained for particular digests, and this accounts for discrepancies in chromosome numbers (for example, only 55 TaqI results were obtained for the $\mathrm{CL} / \mathrm{P}$ cases). This table shows a highly significant association between the TGFA/TaqI C2 RFLP and the occurrence of clefting $\left(\chi^{2}=15.04, p=<0.001\right)$. No significant association was found for the other two enzymes studied.

Haplotypes at the TGFA locus were derived from the three RFLPs where possible, and compared between cases and controls (table 6 ). The total number of haplotypes that could be derived in the two populations were almost equal. The distribution of haplotypes showed that a significant part of the difference between cases and controls was because of the overrepresentation of the $\mathrm{C} 2 \mathrm{~A} 2 \mathrm{~B} 2$ haplotype in cases $\left(41 \%\right.$ of the total Pearson $\chi^{2}$ of 10.34$)$, with the A2 and B2 alleles occurring together owing to linkage disequilibrium (see control chromosomes in table 6).

Genotypes for the TaqI RFLPs were compared in cases and controls. Homozygosity for the C2 allele was significantly more common in cases than controls $\left(\chi^{2}=12 \cdot 05, \mathrm{p}=<0.01\right)$. Genotypes were then analysed according to the presence or absence of a family history of clefting (table 7) and also by type of cleft (whether unilateral or bilateral) (table 3). Twenty-one CL/P subjects, out of a total of 57, gave a positive family history of another relative with $\mathrm{CL} / \mathrm{P}$. Of these, eight $(38 \%)$ carried at least one copy of the rare $\mathrm{C} 2$ allele, compared with $11(31 \%)$ of the 36 sporadic cases (difference not significant).

No significant difference was found between genotype and the presence of a family history of clefting $\left(\chi^{2}=2 \cdot 71, p=>0 \cdot 1\right)$. Although the numbers are small, three out of four cases with a C2C2 genotype had a family history of clefting, and this represents $59 \%$ of the total $\chi^{2}$.

Analysing the data by cleft type also showed no significant difference between genotype and type of cleft $\left(\chi^{2}=4.43, p=>0 \cdot 05\right)$. However, it was noted that the three familial cases with the C2C2 genotype were also those cases with the severe bilateral type of CL/P.

\section{Discussion}

The finding of a highly significant association between the TaqI C2 allele of the TGFA gene and $C L / P$ supports the suggestion that this gene (or another very closely linked to it) plays some part in the development of orofacial clefting. Further analysis of the results shows an excess of the C2A2B2 haplotype in cases over controls, even allowing for the possibility that bias had been introduced (see Materials and methods), and also that the presence of homozygosity for the $\mathrm{C} 2$ allele is particularly significant. These results, combined with the findings of the two other groups, ${ }^{12}$ suggest that a mutation in the same gene (TGFA) underlies a proportion of clefting in all three populations studied (American, Australian, and British), which are predominantly of northern European origin. The fact that both our study and 
Table 5 RFLP distribution and $\chi^{2}$ analysis.

\begin{tabular}{lcccccc}
\hline Probe & Enzyme & Allele* & $\begin{array}{c}\text { No of CL/P } \\
\text { chromosomes }\end{array}$ & $\begin{array}{c}\text { No of control } \\
\text { chromosomes }\end{array}$ & $\chi^{2}$ & p \\
\hline TGFA & TaqI & C1 & 87 & 115 & 15.04 & $<0.001$ \\
& BamHI & A1 & 23 & 5 & & \\
& & A2 & 14 & 16 & 0.06 & NS \\
& RsaI & B1 & 45 & 104 & & \\
& & B2 & 69 & 72 & 0.37 & NS \\
\hline
\end{tabular}

*Alleles as in Human Gene Mapping 10 (1989).

that of Ardinger et al found the C2A2B2 haplotype to be overrepresented in cases, compared to the control population, suggests that a mutation has occurred in a common ancestral gene of northern European origin. Sequence analysis should permit the identification of mutations which presumably could alter the timing, or the spatial characteristics, of the tissue specific expression of TGFA during lip and palate formation.

Although the numbers for the analysis of genotype by both family history and cleft type are too small to reach statistical significance, the figures do suggest that the $\mathrm{C} 2 \mathrm{C} 2$ genotype may be more common in both the familial cases and in the more severe types of $\mathrm{CL} / \mathrm{P}$ (three out of four cases with C2C2 were familial, and the same three cases also had bilateral $\mathrm{CL} / \mathrm{P})$. Cases with bilateral $\mathrm{CL} / \mathrm{P}$ are usually given a higher empirical recurrence risk than unilateral cases. It would certainly be worth combining the world data for these parameters in order to clarify this issue by providing sufficient numbers for further statistical analysis.

TGFA would appear to be a logical choice as a candidate gene in linkage studies using familial cases of $\mathrm{CL} / \mathrm{P}$, but our findings, ${ }^{6}$ and a brief

Table 6 TGFA haplotype data.

\begin{tabular}{lcc}
\hline Haplotype* & CL/P chromosomes & Control chromosomes \\
\hline C2A2B2 & 12 & 4 \\
C1A2B2 & 46 & 60 \\
C1A2B1 & 25 & 25 \\
C1A1B1 & 3 & 4 \\
C2A2B1 & 2 & 1 \\
C2A1B1 & 3 & 0 \\
C2A1B2 & 1 & 0 \\
Total & 92 & 94
\end{tabular}

* Derived for both chromosomes from each person, using alleles from TaqI, BamHI, and RsaI digests.

Table 7 Genotype data by family history.

\begin{tabular}{|c|c|c|c|c|}
\hline \multirow[b]{2}{*}{ Genotype } & \multicolumn{3}{|c|}{$\begin{array}{l}\text { No of CL/P cases by family } \\
\text { history }\end{array}$} & \multirow{2}{*}{$\begin{array}{l}\text { No of } \\
\text { controls }\end{array}$} \\
\hline & Positive & Negative & Total & \\
\hline $\begin{array}{l}\mathrm{C} 2 \mathrm{C} 2 \\
\mathrm{C} 1 \mathrm{C} 2 \\
\mathrm{C} 1 \mathrm{C} 1\end{array}$ & $\begin{array}{r}3 \\
4 \\
10\end{array}$ & $\begin{array}{r}1 \\
10 \\
25\end{array}$ & $\begin{array}{r}4 \\
14 \\
35\end{array}$ & $\begin{array}{r}0 \\
5 \\
54\end{array}$ \\
\hline Total & 18 & 36 & 54 & 59 \\
\hline
\end{tabular}

report published in $1990,{ }^{12}$ have failed to show linkage in families with dominantly inherited $\mathrm{CL} / \mathrm{P}$. This discrepancy needs to be explained. It is possible that TGFA plays a part in many sporadic cases of $\mathrm{CL} / \mathbf{P}$, but not in familial cases, in which presumably some other major gene or genes are the cause. However, our data do not support this suggestion, as the association with the $\mathrm{C} 2$ allele is similar in both familial and sporadic cases.

An alternative explanation is that the $T a q I$ $\mathrm{C} 1$ allele is actually protective against other genetic or environmental factors causing $\mathrm{CL} /$ P. TGFA was initially selected as a potential candidate gene because of its known role in palatal development, regulating the differentiation and proliferation of palatal epithelial cells. It is possible that the $\mathrm{C} 1$ allele modifies the expression of TGFA during lip and palate formation, and, for example, causes early closure. This might counteract other putative 'clefting' genes that predispose to late closure of the maxillary processes or palatal shelves or both. In this respect, the presence of one or more copies of the $\mathrm{Cl}$ allele may be one possible explanation for the occurrence of non-penetrant family members in otherwise dominant $\mathrm{CL} / \mathrm{P}$ families. This possibility should be considered in future work with TGFA.

This work was generously supported by the Medical Research Council and the Child Health Research Appeal Trust. Thanks also go to all the patients who helped with the study, and especially to CLAPA for support and encouragement.

1 Ardinger $\mathrm{HH}$, Buetow $\mathrm{KH}$, Bell $\mathrm{GI}$, Bardach $\mathrm{J}$, VanDemark DR, Murray JC. Association of genetic variation of the transforming growth factor-alpha gene with cleft lip and palate. Am $\mathcal{F}$ Hum Genet 1989;45:348-53.

2 Chenevix-Trench G, Jones K, Green A, Martin N. Further evidence for an association between genetic variation in transforming growth factor-alpha and cleft lip and palate. Am $\mathcal{F}$ Hum Genet 1991;48:1012-3.

3 Fraser FC. Mapping the cleft lip genes: the first fix? $A m \mathcal{J}$ Hum Genet 1989;45:345-7.

4 Carter CO. Genetics of common disorders. Br Med Bull 1969;25:52-7.

5 Chung CS, Bixler D, Watanabe T, Koguchi H, Fogh-Anderson P. Segregation analysis of cleft lip with or without cleft palate: a comparison of Danish and Japanese without cleft palate. a comparison of Dan

6 Vintiner GM, Holder SE, Winter RM, Malcolm S. No evidence of linkage between the transforming growth factor-alpha gene in families with apparently autosomal factor-alpha gene in families with apparently autosomal
dominant inheritance of cleft lip and palate. $\mathcal{f}$ Med Genet 1992;29:393-7.

7 Jeanpierre $K$. A simple method for the purification of DNA from blood. Nucleic Acids Res 1987;15:9611.

8 Southern M. Detection of specific sequences among DNA fragments separated by gel electrophoresis. $\mathcal{f} \mathrm{Mol} \mathrm{Biol}$ 1975;98:503-17.

9 Hayward NK, Nancarrow DJ, Bell GI. A Taq1 polymorphism for the human transforming growth factor alph (TGFA). Nucleic Acids Res 1987;15:5503.

10 Murray JC, Buetow KH, Bell GI. RFLPs for transforming growth factor alpha (TGFA) gene at 2p13. Nucleic Acids Res 1986;14:5117.

11 Tolarova M. Orofacial clefts in Czechoslovakia. Scand $\mathcal{f}$ Plast Reconstr Surg 1987;21:19-25.

12 Hecht JT, Wang Y, Blanton SH, Daiger SP, Michels VV. Nonsyndromic cleft lip with or without cleft palate: no evidence of linkage to tran Am f Hum Genet 1990;47(suppl):220A. 